\title{
Making connections: Social networks in international business
}

\author{
Ilya R. P. Cuypers ${ }^{1}$, \\ Gokhan Ertug ${ }^{1}$, \\ John Cantwell ${ }^{2}$, Akbar Zaheer ${ }^{3}$ \\ and Martin Kilduff ${ }^{4}$ \\ ${ }^{1}$ Lee Kong Chian School of Business, Singapore \\ Management University, Singapore, Singapore; \\ ${ }^{2}$ Rutgers Business School, Rutgers University, \\ New Brunswick, USA; ${ }^{3}$ Carlson School of \\ Management, University of Minnesota, \\ Minneapolis, USA; ${ }^{4}$ School of Management, \\ University College London, London, UK

\section{Correspondence:} \\ IRP Cuypers, Lee Kong Chian School of \\ Business, Singapore Management University, \\ Singapore, Singapore \\ e-mail: ilyacuypers@smu.edu.sg
}

\begin{abstract}
Insights from social network research have generated significant advancements in disciplines such as sociology, economics, and psychology. In comparison, the incorporation of social network ideas into international business (IB) research remains more limited. The purpose of this special issue is to foster further research on social networks in IB. In our introductory essay, we provide a brief overview of network research in the IB domain to give a sense of some of the major ongoing themes and to illustrate how the social network approach can provide fresh insights and add substantive value to the field. To emphasize the considerable potential of using social network theories and ideas to advance research and understanding in $\mathrm{IB}$, we also indicate some future directions. We follow these with a summary of the five articles in the special issue.
\end{abstract}

Journal of International Business Studies (2020) 51, 7|4-736.

https://doi.org/ 10.1057/s41267-020-00319-9

Keywords: social networks; network theory; network analysis; multinational firms; interorganizational ties; subsidiary-HQ relationships; inter-personal ties; inter-location ties; literature review

\section{INTRODUCTION}

The progress of research on social networks has enabled the increasingly fruitful application of network ideas across disciplines (e.g., Barabasi, 2002; Burt, Kilduff, \& Tasselli, 2013; Christakis \& Fowler, 2009; Jackson, 2008). In addition to its longstanding and ongoing prominent role in sociology, the network perspective has yielded, and continues to yield, significant advancements in economics, psychology, and inter-disciplinary research.

Considering the prominence of the social network perspective in its instantiations across business disciplines, its incorporation into international business (IB) research remains limited by comparison. Relatedly, many IB studies have used networks predominantly in primarily a metaphorical sense (Ghoshal \& Bartlett, 1990). Nevertheless, there are studies that have drawn more explicitly from social network theory and methods to explore IB-related questions (e.g., Ghoshal \& Barlett, 1990; Vasudeva, Zaheer, \& Hernandez, 2013; Haas \& Cummings, 2015). These examples illustrate the rewards to applying social network theories in IB research. Therefore, through this introductory essay, and the articles in this special issue, we seek to foster further research on social networks in IB.
Received: 29 October 2019

Revised: 29 January 2020

Accepted: 20 February 2020

Online publication date: 2 April 2020 
In this essay, we provide a brief overview of the network perspective and network research in IB. In doing this, we touch upon some articles to illustrate the themes that we observe in work that has appeared across the spectrum of journals that publish research on IB, focusing mostly on research published in the last two decades onward. Rather than attempting to be comprehensive in this brief review, our aim is to provide a sense of some of the ongoing themes and recent directions that investigate IB-related phenomena at different levels that use network arguments, measures, or methodology. In some cases, these components constitute the core of the article, whereas in others they are employed to investigate intervening mechanisms and boundary conditions, or as an empirical tool in operationalization (mostly) or estimations (rarely). Throughout this brief overview of network research in IB, we also refer at times to more general non-IB network work when we believe that this helps position the work that has been done in IB. In each of these sections on research at different levels, we also note a number of directions for future research, following our review of key themes and directions. In these brief sections, we touch upon some points that we see as gaps in the IB literature, considering the broader literature on social networks outside IB.

Before delving into the different areas that characterize the social network research within the IB arena, it is helpful to set the stage in terms of network research more generally. The social network approach is unusual in bringing a distinctive theoretical and methodological lens to bear upon different levels of analysis. Whether the analysis is at the individual, organizational, interorganizational, or inter-geographical level, the network perspective exploits its core ideas to identify research opportunities. A social network, at any level, can be defined as a set of nodes as well as the connections and the absence of connections between these nodes. The core ideas that are brought to bear upon a network of people or organizations include the following four interrelated concepts that drive much of the research agenda: the importance of relationships between actors, the embeddedness of exchange within social relationships, the structural patterning of relationships in terms of centrality and peripherality, and the advantages versus disadvantages of network connectedness (Kilduff \& Brass, 2010).

The first leading idea, the importance of relationships, is implicit in nearly all research on multinational corporations (MNCs), given the attention focused on $\mathrm{HQ} /$ subsidiary engagement (see Kostova, Marano, \& Tallman, 2016, for a review). From a social network perspective, it is through relationships that knowledge is transferred by, for example, the movement of personnel between subsidiaries (Cheong, Sandhu, Edwards, $\&$ Poon, 2019) or the provision of advice from one subsidiary to another (Tsai, 2001).

Embeddedness is a key concept in network research and in IB research, building on the influential work of Granovetter (1985) and Uzzi (1997). Actors, either individuals or organizations, are embedded within a network to the extent that they show a preference for repeat transactions with network members, and to the extent that ties are created, renewed, and extended through the network of connected actors rather than through outside actors (e.g., Gulati \& Gargiulo, 1999). There is a vibrant history of research on embeddedness within IB (see Heidenreich, 2012, for a review). For example, recent research contrasts the effects of internal embeddedness versus external embeddedness on global knowledge sourcing by research and development subsidiaries (Asakawa, Park, Song, \& Kim, 2018).

A third leading idea important for IB research from a network perspective is structural patterning. Network research allows the study of the whole and the parts of social networks simultaneously (Wellman, 1988). The parts of the network include dyads (e.g., two subsidiaries connected through a knowledge transfer arrangement), triads (e.g., three subsidiaries that share the same HRM practice), cliques (e.g., three or more subsidiaries who preferentially share R\&D with each other), and larger structures such as components (i.e., a set of organizations that can all reach each other through alliance ties; see Powell, Koput, \& Smith-Doerr, 1996). In principle, it is possible for research to address all these levels simultaneously, although this is almost never achieved in practice. Instead, there is intense interest in looking at the whole network and the extent to which organizations occupy different positions within the network. For example, units that are central within the knowledge transfer network of the MNC gain advantages over their rivals in terms of innovation and performance (e.g., Tsai, 2001).

Relatedly, therefore, the social network perspective emphasizes that social network relationships provide opportunities and constraints that affect the outcomes that people and organizations care about. As the previous example (Tsai, 2001) 
illustrates, centrality within a network typically provides benefits. More generally, different configurations of inter- and intrafirm network structures influence the ability of multidivisional firms to acquire knowledge from alliance partners and to diffuse such knowledge across business units (Walter, Lechner, \& Kellermans, 2007). Within network research, the structural hole perspective has been the major vehicle through which advantages and disadvantages of network positions have been explored (Burt, 1992). One influential study examined a longitudinal dataset comprising the linkage and patenting activities of 97 leading firms from the chemicals industry in Western Europe, Japan, and the United States. The results showed that, in this particular interfirm technology linkage network, direct and indirect ties influenced innovation output positively, but the impact of indirect ties was moderated by the firm's level of direct ties. And, surprisingly, as the number of structural holes increased in the interfirm collaboration, innovation output decreased (Ahuja, 2000). Similarly, for a population of 4088 banks engaged in foreignexchange trading, results showed a significant negative relationship between the bridging of structural holes in a bank's information network and the extent of the bank's market influence (Zaheer \& Zaheer, 1997). By contrast, at the individual level, recent research concerning 276 scientists, researchers, and engineers, from the $R \& D$ division of a large multinational high-tech company, showed that the effects of external knowledge on innovation generation become more positive when individuals sourcing external knowledge spanned structural holes in the internal knowledge-sharing network (Tortoriello, 2015). Moreover, there is a major debate regarding the value of brokerage and closure in social network research (e.g., Burt, 2005; Gargiulo, Ertug, \& Galunic, 2009; Carnabuci \& Diószegi, 2015) that has important implications for research on social networks in IB.

These leading ideas of the organizational network research program represent the basis from which innovative research springs. In the following review of network research in IB, the importance of network relationships is taken as given, and there is particular emphasis on social network embeddedness and network position. We organize our review by level of analysis, starting with the interpersonal level and ending with the regional and country levels. ${ }^{1}$ For each of these levels, we discuss themes, findings, insights, and directions for future research. We then position the articles in the special issue and their contributions to the literature, and end with a brief conclusion.

\section{INTER-PERSONAL NETWORKS IN INTERNATIONAL BUSINESS}

While perhaps smaller in volume than work at other levels, research on interpersonal networks in IB spans a wide variety of topics. To make sense of this variety, we organize this section into empirical research on embeddedness, boundary spanning, and knowledge transfer, which we follow with a sub-section on conceptual and theoretical papers.

\section{Embeddedness}

A core concept in social network research is embeddedness, which refers to the overlap between social ties and economic ties, or the nesting of social ties within other ties (Kilduff \& Brass, 2010). In the IB arena, the term has taken on a variety of related uses. For example, the extent to which expatriates are autonomously motivated predicts embeddedness in the sense of feeling connected to an organization or a community (Chen \& Shaffer, 2017). Embeddedness also refers to the extent to which an individual relies on online social connections through LinkedIn, and this type of embeddedness provides resources and protects against opportunism (Sigfusson \& Chetty, 2013). In addition, embeddedness in terms of friendly relationships between venture capitalists and those who refer them to entrepreneurs leads to positive investment decisions (Batjargal, 2007). Embeddedness in small dense networks facilitates early-stage international new venture development, but is less useful as the venture evolves (Coviello, 2006). Ethnic networks that stretch across borders facilitate cross-border venture capital flows; these flows are, therefore, embedded in transnational communities (Madhavan \& Iriyama, 2009). Embeddedness also encompasses the extent to which individuals develop local environmental ties as opposed to MNC organizational ties (Newburry \& Yakova, 2006), and the extent to which economic actions that are embedded in social relationships nurture those relationships so that they become more trusting and collaborative (Su, Yang, Zhuang, Zhou, $\&$ Dou, 2009).

Firm embeddedness, in terms of the social ties between business owners within a community, both constrains and enables firm-level outcomes (Uzzi, 1997). Thus, the high level of social ties in a 
region creates multiple channels for contacts between managers and employees of firms, making it easier for firms to obtain knowledge about opportunities in foreign markets. Business relationships embedded in social relationships tend to affect outcomes in transitional economies relative to market economies (Luk, Yau, Sin, Alan, Chow, \& Lee, 2008). Managers rely more on relational ties as asset specificity and uncertainty increase (Zhou, Poppo, \& Yang, 2008). However, as ties become denser, there is an increasing likelihood that firms will interact only with local actors rather than pursuing foreign markets (Laursen, Masciarelli, \& Prencipe, 2012). At the same time, potentially lucrative opportunities for entrepreneurs lie beyond embeddedness within their international communication networks (Ellis, 2011).

Embeddedness in social networks inhibits opportunism (Granovetter, 1985). A study of 192 international joint ventures found that, within collectivist versus individualist cultures, interparty attachments and boundary-spanning ties were stronger inhibitors of opportunism (Luo, 2007). A related finding is that, among managers, affect- and cognition-based trust is more intertwined in the collectivist culture of China relative to the individualist culture of the USA (Chua, Morris, \& Ingram, 2009). For partnerships between Western-based and Eastern-based firms, commitment to further exchanges predicts export performance, and is itself driven by the reciprocal cycle of each partner's perception of the other's commitment (Styles, Patterson, \& Ahmed, 2008).

\section{Boundary Spanning}

Boundary spanning is also an important topic in social network research. Contacts across international boundaries provide knowledge of market opportunities (Ellis, 2000). In the case of expatriates, their boundary spanning activities are facilitated to the extent that they gain local experience and build diverse social networks (Au \& Fukuda, 2002). In a Chinese context, boundary spanners in supplier firms use personal network connections to influence retailers when dependence on retailers is high (Su et al., 2009). For Chinese firms, managerial ties with foreign suppliers, competitors, and customers have a positive (albeit mediated) effect on international performance (Lu, Zhou, Bruton, \& Li, 2010). Foreign firms within China benefit from their use of business ties, but profitability suffers if they rely heavily on political ties (Li, Zhou, \& Shao, 2009).
A qualitative study of expatriates confirmed that the boundary spanning role is, as agentic social network research would predict, concerned with building and maintaining relationships with agents external to the organization, often with diplomats or government officials (Johnson \& Duxbury, 2010). A more recent combined quantitative and qualitative analysis showed that key boundary spanners possess rare and difficult-to-imitate abilities, including cultural and language skills (BarnerRasmussen, Ehrnrooth, Koveshnikov, \& Makela, 2014). In the context of China, some Chinese managers in foreign-owned companies acquire, crosscheck, and filter information from client companies and other sources that is only made available to them as members of the relevant guanxi network (Gao, Knight, Yang, \& Ballantyne, 2014). Research also emphasizes the importance of language skills. For example, to the extent that Czech CEOs and their international contacts share the same languages, the CEOs' firms are able to internationalize faster (Musteen, Francis, \& Datta, 2010). In general, individuals with more cultural identities tend to have more social capital and higher levels of intercultural skills than those with fewer cultural identities (Fitzsimmons, Liao, \& Thomas, 2017).

Social network brokerage is a form of boundary spanning often studied in Western contexts, and sometimes claimed to be less effective in collectivist cultures (e.g., Xiao \& Tsui, 2007). However, recent evidence showed, for a large sample of Chinese entrepreneurs, that business success was associated with networks rich in structural holes, a finding in line with prior research in Western contexts (Burt \& Burzynska, 2017: 238). However, guanxi ties, defined as those in which trust was high and relatively independent of the social structure around the relationship, were over six times higher in this Chinese sample relative to a U.S. sample of bankers and analysts (Burt \& Burzynska, 2017: 240). There are differences, therefore, in Chinese relative to U.S. social networks, but the evidence suggests that brokerage and closure operate similarly in the two contexts.

\section{Knowledge Transfer}

Turning to research on knowledge transfer, we note that a basic challenge facing the multinational corporation is the facilitation of learning across different divisions and countries. One study of a large MNC across over 13,000 dyadic interactions showed that barriers to knowledge seeking were 
greater across geographic differences compared to nationality differences: people based in different parts of the world were less likely to seek knowledge from each other than were people of different nationalities (Haas \& Cummings, 2015). Relatedly, people working within subunits of the MNC can gain innovative ideas from non-employees who work in the local environment, as well as from employees who work in subunits based across national borders (Morris, Hammond, \& Snell, 2014). Firms also gain knowledge from directors who sit on other company boards, including knowledge concerning how to expand into foreign markets (Ang, Benischke, \& Hooi, 2018).

One of the prime sources of new knowledge comes not from directors but from returnees to their home countries from foreign assignments or foreign educational training. Returnees are likely to use this knowledge to facilitate their entrepreneurial initiatives, especially if the home country provides support policies for returnee entrepreneurship (Lin, Lu, Liu, \& Zhang, 2016). Firms started by returnee entrepreneurs are more innovative than firms started by local entrepreneurs in the case of China (Liu, Lu, Filatotchev, Buck, \& Wright, 2010). Returnees to China and other countries who have been trained in the U.S. in corporations such as Google and Merrill Lynch are more successful at transferring knowledge to their home-country employers if the returnees have been embedded (e.g., completed a degree) in both the U.S. and the home country. However, home-country xenophobia diminishes the positive effect of host-country embeddedness while increasing the positive effect of home-country embeddedness (Wang, 2015). Along these lines, business knowledge obtained from interpersonal ties in more developed countries is not always more useful than locally sourced knowledge. Overseas knowledge is preferable when new-to-the-industry knowledge is needed, when there is a strong tie, and when the knowledge does not involve a long discussion, but otherwise local knowledge is preferable (Levin \& Barnard, 2013).

Knowledge seeking is an instrumental relationship in that one person seeks resources from another. Valuable knowledge is often found from people who are different from oneself (e.g., Ertug, Gargiulo, Galunic, \& Zou, 2018). Thus, it is not surprising that, within the multinational enterprise, strong instrumental ties tend to form between managers who differ in nationality and in residency status (i.e., local vs. expatriate). In contrast, strong expressive ties, such as friendship, tend to form between managers who are similar in these characteristics (Manev \& Stevenson, 2001). Is it similarity or difference in relationship to social ties that drives strategic decisions? Firms' decisions concerning the locations of offshore service units are significantly affected by ethnic similarity in the case of Indian CEOs (Zaheer, Lamin, \& Subramani, 2009). Leaders of multinational teams are more likely to profit from the local knowledge of employees from underrepresented nationalities when the CEOs share the same nationality (Tröster \& van Knippenberg, 2012). In terms of language, MNCs who recruit on the basis of competence in English may facilitate knowledge transfer between subsidiaries and headquarters but may pay a penalty in terms of acquiring less knowledge transfer from local environments (Peltokorpi \& Vaara, 2014). Companies that make use of the local lingua franca tend to benefit in terms of better stakeholder relationships (Selmier II, Newenham-Kahindi, \& Oh, 2015).

For expatriates within MNCs, interactions with host-country colleagues tend to improve performance through the provision of new knowledge (Bruning, Sonpar, \& Wang, 2012). Indeed, having a host-country mentor significantly increases expatriate knowledge sharing, whereas having a homecountry mentor negatively affects expatriate organization identification and job satisfaction (Carraher, Sullivan, \& Crocitto, 2008).

\section{Conceptual and Theoretical Perspectives}

Social network research at the interpersonal level concerning IB also incorporates a set of conceptual approaches. In the context of negotiations and bargaining in the international arena, national culture is hypothesized to affect the extent of clique formation with consequences for the type of problem-solving approach and the extent to which outcomes are creatively beneficial (Money, 1998). Relationships among international bargaining participants, including relationships among nation states, multinational enterprises, NGOs, and multilateral organizations, can be modeled as a network that highlights the importance of understanding coalitions and differences in actor power (Nebus \& Rufin, 2010). Along these lines, the multinational corporation can be modeled as a multilingual community in which parent functional language and subunit functional languages are concurrently used and linked through an intracorporate communication network (Luo \& Shenkar, 2006). Within such a network, there is interest 
in modeling the ways in which human capital and social capital interact to affect employee development and knowledge transfer (Crane \& Hartwell, 2019). Repatriates (i.e., people who return from foreign assignments to their domestic organizations), in particular, may be able to share valuable knowledge depending on managerial and organizational characteristics of the domestic organization (Oddou, Osland, \& Blakeney, 2009). Managers in smaller organizations engaged in export activities can gain resources and knowledge from personal contacts, including former colleagues, relatives, and personnel in supplier companies (Andersen, 2006). For managers in larger companies, there is the possibility that individual level social capital provides the foundation for the development of firm-level social capital (Griffith \& Harvey, 2004).

\section{INTER-SUBSIDIARY NETWORKS IN INTERNATIONAL BUSINESS}

In this section, we review work that touches upon networks and investigates phenomena at the subsidiary level [by which we generally mean research at the subsidiary, inter-subsidiary, headquarter (HQ)/MNC, and HQ-subsidiary levels, although we also refer to other work], including much work that builds on Ghoshal and Bartlett's (1990) conceptualization of the MNC as an interorganizational network.

We will touch upon three themes, which are (1) knowledge transfer/learning, (2) autonomy, influence, power, and (3) performance. The grouping and the labels we use are meant to provide an idea of themes, rather than being mutually exclusive, if for no other reason than the fact that matters of learning, influence, and performance are not independent of each other. ${ }^{2}$

\section{Knowledge Transfer and Learning}

One major theme of ongoing concern is knowledge transfer or learning, which is mostly considered as occurring inter-unit (inter-subsidiary) or between the HQ and subsidiary (in either direction). The level of interest in research on these phenomena is to be expected, given their importance for the parties concerned (subsidiaries, the HQ, and external partners) and the challenges involved. The primarily positive function of relationships, social capital, and networks on facilitating, enhancing, and enabling knowledge transfer and learning have been well documented. Most studies use survey data, which is to be expected given the constructs of social ties, networks, or networking that usually call for this methodology. Learning and knowledge transfer have also generally been measured using surveys.

To illustrate the main findings in this stream of work with some examples, using data from 140 international joint ventures (IJVs) that operate in Hungary, Dhanaraj, Lyles, Steensma, and Tihanyi (2004) find that embeddedness (as captured by parent-IJV tie strength, trust, and shared systems, which the authors refer to collectively as social or relational embeddedness) influences the type of knowledge transferred from the parent to the IJV (finding these to be a stronger predictor of tacit than of explicit knowledge transfer), as contingent on the age of the IJV. A contemporaneous study of 134 Western subsidiaries located in Finland and China, by Björkman, Barner-Rasmussen, and Li (2004), also finds that corporate socialization mechanisms (such as inter-unit trips, international committees, and training programs with participants from multiple units) are positively related to inter-unit knowledge transfer. Continuing this theme, using survey data collected from the managers of 163 subsidiaries in a multi-country sample, Venaik, Midgley, and Devinney (2005) find that inter-unit networking is positively related to inter-unit learning, and they also observe a smaller and statistically weaker relationship of such networking to subsidiary performance. Also investigating the topic of social interactions and knowledge-sharing within MNCs, drawing from the sender-receiver model and social learning theory, Noorderhaven and Harzing (2009) find, using data from 169 subsidiaries of nearly $50 \mathrm{MNCs}$, that social interactions (taking place between managers from different subsidiaries of the MNC) are positively related to within-MNC knowledge flows, and the authors also explore contingencies with intriguing implications.

As the studies reviewed above and many others have documented evidence of the (primarily positive) effect of networks and networking on knowledge transfer and learning, some recent studies take this link as assumed (as the operating mechanism that is not then necessarily directly measured or observed) in deriving their hypotheses. For example, Dau (2018), using multi-year data on the largest Latin American companies, suggests that a parent firm's centrality in its network of subsidiaries makes the firm learn faster through its subsidiary network configuration, yielding the (supported) prediction that it thereby positively 
moderates the effect of pro-market reforms on profitability. Other recent studies continue to investigate the implications of more granular or different types of network mechanisms for knowledge-related outcomes. For example, Asakawa et al. (2018) use data on $99 \mathrm{R} \& \mathrm{D}$ subsidiaries of 62 Japanese MNCs to predict and find that different types of vertical embeddedness (administrative vs. knowledge) have different implications for global knowledge sourcing by these subsidiaries. Vertical administrative embeddedness obstructs such sourcing, whereas vertical knowledge embeddedness facilitates it.

\section{Subsidiary Power, Autonomy, and Influence}

A second major theme converges around the issues of the power, autonomy, and influence of the subsidiary, which are also inherently related to the power, influence, and control of the HQ over its subsidiaries. Studies in this theme have used different ways to measure network ties, network structure, and networking activities, and have also drawn from related arguments, including those about issues of power and politics.

Using survey data from 275 UK subsidiaries of non-UK firms to test their hypotheses, Mudambi and Navarra (2004) developed in detail the idea that knowledge flows within MNCs are an important factor of the bargaining power of and rent appropriation by subsidiaries. Categorizing multiple types of knowledge flows that involve subsidiaries, and taking into account modes of entry as well as research intensity, the authors investigate the sources of knowledge output and bargaining power of a subsidiary, the role of knowledge output as a determinant itself of bargaining power, and the relationship between bargaining power and rent appropriation by the subsidiary. Andersson, Forsgren, and Holm (2007) develop a model, which they test with data from 97 subsidiaries of 20 MNCs, that considers the MNC as a federation (an arena for bargaining) to analyze the source of the influence and autonomy of subsidiaries (their specific and close external business ties), and how the HQ can counteract and reduce such influence and autonomy (based on HQ's knowledge of a given subsidiary's business network). Dörrenbächer and Gammelgaard (2010) analyze the case of a charter removal of a Hungarian subsidiary of Siemens to study how both the resources (in this case, the specialization) and the network attributes and position (network density) of a subsidiary can influence (in this case reduce) its network centrality, thereby making more likely the removal of its charter. Again touching upon matters of power, using a critical discursive perspective, Balogun, Jarzabkowski, and Vaara (2011) study the case of a European subsidiary of an MNC to suggest how resistance, and the related dynamics power and politics, are an important part of integration.

Unpacking some of the mechanisms through which the network(ing) influence links work, Najafi-Tavani, Giroud, and Andersson (2014) use data on 184 subsidiaries in the UK that are foreign owned to suggest that the widely assumed effect of a subsidiary's networking activities on its influence are largely mediated by the presence of knowledgebased activities. Even though the authors note that network activities are nevertheless an important constituent of a subsidiary's power base, their analyses suggest that the effect of such activities on influence are primarily indirect, as obtaining through knowledge development and issue-selling activities. In this vein, Chung, Lee, Beamish, and Isobe (2010), using data on 1519 subsidiaries of 471 Japanese corporations in 5 Asian countries, argue for the related point that network characteristics of subsidiaries are not the sole determinants of their expansion or contraction, but that these need to be considered in conjunction with the real options orientations of those same subsidiaries to understand the role they play in such expansion or contraction. In contrast to the primarily static view of most of the quantitative work in this area, Ambos, Asakawa, and Ambos (2011) take a more dynamic view and use data from 73 overseas $R \& D$ subsidiaries of German firms to consider the matter of subsidiary autonomy in both a static and dynamic manner. The authors suggest that internal embeddedness and external embeddedness have nuanced (and indeed at times opposite) effects on subsidiary autonomy, based on whether one is considering the subsidiary's current level of autonomy or its autonomy in the future. Concluding our overview of this theme with a study that again touches upon when the MNC might choose to develop linkages that have implications for the power, influence, and autonomy of a subsidiary, Nell, Ambos, and Schlegelmilch (2011) use data on 168 European subsidiaries to study when MNCs develop linkages that overlap with those of their local subsidiaries (resulting in an overlap of embeddedness in their external networks), finding that this happens more when the subsidiary in question is a high performer, holds important resources, operates in turbulent environments, and is closely 
connected to multinational (rather than domestic) actors.

\section{Performance Implications of Subsidiary Networks} As a third theme, we consider studies that investigate the mostly performance-related implications of the subsidiary network on the HQ or the MNC itself, or the case of the implications of the MNC or subsidiary network on the performance of a given subsidiary. As we have noted, some of these studies can also be understood as knowledge-transfer/ learning or influence/autonomy/power-related, since both of those sets of concerns have implications for performance. An earlier piece (Allen \& Pantzalis, 1996), using archival data on 363 MNCs, considers the breadth (number of countries in which the MNC has subsidiaries) and depth (the concentration of subsidiaries) of the geographic network of an MNC's subsidiaries to show that returns to multinationality (understood and estimated as value of operating flexibility) are maximized for MNCs with subsidiary networks that are geographically broad but not deep. In a related endeavor, Lee and Makhija (2009) consider firm value (as Tobin's Q), using data on 270 Korean firms over 1990-2006, and predict and find that a subsidiary network that is both less broad (in terms of the number of countries) and less deep (in terms of concentration) is positively related to firm value. Elango and Pattnaik (2007), using data on a sample of 794 Indian firms, look into the case of how a firm in an emerging market can build capabilities for their international operations through leveraging and learning from parental networks (measured as the ratio of sales from foreign countries to sales overall). In their study of firm-specific advantages, Scott-Kennel and Giroud (2015) use survey data from a multi-country sample of 180 HQs and 167 foreign subsidiaries to study the relationship between internal (other units of the MNC) and external (business partners in the environment) network knowledge on the one hand and subsidiary-specific and HQ-specific advantage on the other. Their finding is that, whereas external network knowledge is relevant for both a subsidiary's and HQ's advantage, internal network knowledge also helps HQ's advantage, but in fact has a primarily negative relationship with a subsidiary's firm-specific advantage.

\section{Other Ongoing Themes and Recent Work}

We touch upon two other themes in recent work to conclude this brief overview. First, there is research that looks into the implications of a subsidiary's network, not on the subsidiary or the $\mathrm{HQ} / \mathrm{MNC}$ as such, but on its contribution to economic development in the host location. For example, Dimitratos, Liouka, and Young (2009) use survey data from 264 subsidiaries (from Japan, US, and Europe) operating in the UK to show that the external (but not internal) networking activities of subsidiaries are positively related to their contribution to the region in which they operate. Beyond contributing to the subsidiary's own performance and that of the $\mathrm{HQ} / \mathrm{MNC}$, as well as to the subsidiary's influence, power, and autonomy in the MNC, a subsidiary's networks and networking activities can also have implications for the region in which it operates, and for public policy, as studies in this direction indicate. Khan, Lew, and Sinkovics's study (2015) can also be considered here, or under the first theme above, depending on one's focus and interpretation. Through interviews with managers of 50 Pakistani Tier 1 suppliers and three IJVs, as well as with the Ministry or Industries and Production, the authors study how IJVs in Pakistan serve an important role, as boundary spanners, in knowledge transfer. What emerges as a key factor in this investigation, to facilitate the boundary spanning role of IJVs and the knowledge transfer to local partners (suppliers), is the social capital between the IJVs and these partners.

Second, research in IB has also been making use of more elaborate network measures, as an aid to more comprehensive incorporation of network ideas and mechanisms, when the ideas being investigated call for it. In a recent example, Iurkov and Benito (2018) use FDI data between 2001 and 2008 from 302 publicly traded US MNCs in information and communication technology (ICT) to study how the positions of MNCs in their domestic network of strategic alliance affect their geographic scope. The authors derive predictions about the effects of network range, brokerage, and cluster density (and also how these effects are attenuated by absorptive capacity) on geographic scope. ${ }^{3}$

\section{INTER-FIRM NETWORKS IN INTERNATIONAL BUSINESS}

It is surprising that the role of networks in IB, particularly of the interfirm variety, has been generally under-researched, given the early recognition of the importance of 'business networks' in the process of the internationalization of firms as spelled out in the 'Uppsala Model' (Johanson \& 
Vahlne, 1977, 2009). Of course, the 'networks' alluded to by these authors were networks in the metaphorical sense, rather than theoretical or methodological treatments drawn from social network analysis that have become commonplace in the strategy and organization literature (Gulati, Nohria, \& Zaheer, 2000; Dhanaraj, 2007; Forsgren, 2016). At the same time, the alliance and networkoriented direction these researchers pointed to in understanding how firms internationalize, and the implied performance outcomes, was unambiguous. The question this raises is: Why have we not seen more exploitation of the potential of network analysis at the interfirm level in IB research, given the outsized nature of its influence in the closely related fields of strategy and organization?

In this section, we consider the contributions of some notable studies that have adopted the network perspective at the interfirm or interorganizational level of analysis in IB. For the sake of clarity and consistency, we restrict ourselves to interorganizational networks in the global space, and exclude networks of suppliers, global supply chains, and intraorganizational networks at the individual and national levels, some of which are addressed elsewhere in this essay. We discuss the literature broadly under the sub-headings of interfirm network outcomes and interfirm networks as moderators, since little work tackles the antecedents of global interfirm networks. We also spell out some challenges and opportunities for interfirm and interorganizational network perspectives in IB.

\section{Interfirm Network Outcomes}

An earlier set of writings that took an explicitly network perspective to IB, and the multinational in particular, is the work by Sumantra Ghoshal, Nitin Nohria and Chris Bartlett (e.g., Ghoshal \& Nohria, 1989, 1993; Bartlett \& Ghoshal, 1989; Ghoshal \& Bartlett, 1990). Although the networks addressed by these authors are networks of MNC subsidiaries, the authors framed the networks in question as 'interorganizational,' not only because they believed that network tools would provide insights and understanding into MNC functioning and outcomes but also because the MNC's headquarters as well as its subsidiaries are embedded in "external networks" in their local contexts. The structure of both the external and the internal networks holds implications for MNC functioning and performance. For example, the authors cite Westney and Sakakibara (1985) to explain how the dense and multiplex knowledge networks in Japan excluded the subsidiaries of US computer company subsidiaries. A counter example was reflected in the case of the Australian subsidiary of Ericsson which developed extensive ties with local suppliers, customers, and regulators, resulting in high levels of research resources and subsidiary autonomy (Ghoshal \& Bartlett, 1990). The authors also invoke the concepts of network centrality in the external and internal networks to explain resource distribution and specialization in the MNC.

Making an interesting linkage between domestic network position and foreign divestment decisions, Iurkov and Benito (2020) show that firms in the ICT industries were more likely to divest foreign operations when they became more central (i.e., increased betweenness centrality) domestically in their alliance networks. The effect was even stronger when firm-specific uncertainty was higher. A strategic outcome of global alliance networks was studied by Xia, Ma, Tong, and Li (2018), who demonstrate that interlocking partners affect MNCs' cross-border acquisitions more than do joint venture partners, due to superior information conveyed by interlocked global networks. Sharma, Kumar, Yan, Borah, and Adhikary (2019) examine the performance outcomes of MNC buyer-supplier networks in 28 countries and show that density negatively affects the MNC's total international revenues, while centralization and average clustering coefficient influence the outcome via invertedU- and U-shaped relationships, respectively. These effects are further moderated by average path length and PageRank centrality. Shi, Sun, Pinkham, and Peng (2014) show that centrality and brokerage in domestic alliance networks help Chinese firms to attract IJV partners. Spencer (2003) shows how density, centralization, and brokerage in a knowledge network of citations by corporate scientists enhance the subsequent competitiveness of a country's firms.

One of the more recent trends in IB involves the successful internationalization of emerging market MNCs, such as China's Huawei or India's Mahindra. Some work attributes at least part of their success, and that of domestic firms in emerging markets, to international and global networks. In this vein, Elango and Pattnaik (2007) build on the Uppsala model to show that the greater the extent to which an MNC's business group network is connected to a larger number of industries, and thus has greater internationalization experience, the more successful it will be at internationalizing. More recently, Eapen (2012) theorizes about how 
domestic firms benefit from technology spillovers from foreign MNCs, proposing that search efficiency is related to the sparseness of network structures and transfer efficiency to their cohesion.

\section{Interfirm Networks as Contingencies}

Mingo, Morales, and Dau (2018) show that centrality in regional interfirm networks affects the relationship between institutional proximity and the likelihood that the firm invests in the emerging market. Vasudeva et al. (2013) explain the outcomes of global interfirm alliance structures by recognizing that such networks are themselves embedded in institutional settings. Specifically, they demonstrate that structural holes in global alliance networks have differing innovation effects for broker firms, depending on the institutional environments of the countries in which they operate. When the broker is located in a corporatist country, such as Japan, where communitarian principles dominate, the $\mathrm{MNC}$ is able to gain innovation benefits from spanning structural holes because it is better able to integrate knowledge. Conversely, when the broker MNC is located in countries with low communitarianism, such as the U.S. or the U.K., innovation benefits are limited. Similarly, when the broker firm's alliance partners are located in low communitarian countries, innovation benefits will be lower, and vice versa.

\section{INTER-LOCATION NETWORKS IN INTERNATIONAL BUSINESS}

In the traditional IB network perspective, as developed by the Uppsala school (see Forsgren, Holm, \& Johanson, 2005), the MNC subsidiary is seen as a network node which has ties with its parent company and various other actors. There is at least an implicit geography in this approach, but this has often entailed little more than a distinction between the home country of the parent and the host country in which the subsidiary is sited. Thus, the business network view has focused on the organizational aspects of the firm's subsidiary network structures, such as the concentration or dispersion of power and control, and the management of technology transfer in the network (e.g., Andersson, Forsgren, \& Holm, 2001; Andersson, Forsgren, \& Pedersen, 2001), while paying less attention to the geography of network ties or network breadth. However, this literature has allowed scholars to clarify the distinction between changing geographies of the MNC due to internationalization processes that are attributable to changes in cross-border ownership through mergers and acquisitions when underlying business network structures remain largely unchanged, and those associated with internationalization processes that result from shifts in the structure of business relationships which extend the reach of the network, such as an increase in subsidiary exports or subsidiary partners and alliances.

\section{International Business Network Structures and Embeddedness}

By way of contrast, although the recently expanded IB network literature has long been grounded in the Uppsala business network approach, newer research has come to use the terminology of embeddedness in a network, often to refer more specifically to a geographically local context (e.g., Asakawa et al., 2018; Cantwell \& Iammarino, 2003). This is a natural extension in the conceptualization of how we think about an IB network, since it follows the equivalent usage of the terminology of local embeddedness in the field of economic geography, especially when referencing the role of clusters (e.g., Li \& Bathelt, 2018). For IB scholars, the existence of local clusters has given rise to discussions of whether foreign-owned MNC subsidiaries may be able to benefit from local knowledge spillovers when located in a cluster, or indeed how they might contribute to a local business network in which they become embedded (Cantwell, 2009). The extent to which an MNC subsidiary can become embedded in local networks in the host region or country depends upon its capacity to become more of an insider and less of an outsider in those networks, and such embeddedness in turn influences a subsidiary's likelihood of playing a competence-creating role within its MNC group (Cantwell \& Mudambi, 2011). Beyond this purely local form of embeddedness, and reflecting the steadily rising significance of a decentralized range of networking efforts for the $\mathrm{MNC}$, in the later versions of the Uppsala internationalization process model, the international growth of the firm has been related to the degree to which it can shift from outsidership and toward insidership in international networks (Johanson \& Vahlne, 2009).

Of course, much still remains to be done for the IB literature to fully incorporate the diversity of ties entailed in a wider cross-border geography of networks. While there have long been hints in 
the literature on the internal networks of the MNC as complex interconnected webs of relationships across distinct national innovation systems (e.g., Cantwell, 1989; Chini, 2004; Hedlund, 1994; Nohria \& Ghoshal, 1997), these have generally focused in practice on parent-subsidiary relationships, and hence in geographic terms on homehost associations. IB scholars have recently begun to consider a more comprehensive set of geographic network structures, borrowing from the toolkit of social network analysis (e.g., Awate \& Mudambi, 2018). Within such structures, it has been established that some prominent MNC subsidiaries in critical locations enjoy a high degree of centrality, yet many other subsidiaries tend to be left in a more isolated position (Monteiro, Arvidsson, \& Birkinshaw, 2008).

\section{Connectivity Across Firms and Places}

Another related strand of IB research has recorded how geographically distant knowledge that is developed in a different institutional context can be accessed through alliance networks (e.g., Rosenkopf \& Almeida, 2003), and how different institutional logics require different kinds of network structure to facilitate knowledge flows between network participants (Vasudeva et al., 2013). Some work has also connected the evolution in the composition of firms in alliance networks to the extent of their insidership in certain pivotal host countries (Zhang \& Pezeshkan, 2016). Firms with critical linkages in key locations can enhance their position further in international networks and become more selective in their choice of partners. The conventional internationalization process model also suggested that the geographic pattern of the international expansion of a firm depends on its existing network ties, and on the ease with which it can transition from operating in one network to entering into others. Also within host countries, the geography of a foreign-owned firm's expansion depends on its participation in ethnic networks or in other local networks, and the geography of connections that these networks facilitate (Stallkamp, Pinkham, Schotter, \& Buchel, 2018).

The growing awareness of the need to recognize the full geography of IB network structures, beyond the earlier focus on home-host country dyads, reflects in part a shift in how IB scholars have understood the attractiveness of a location. While the traditional treatment of the advantages or disadvantages of a host location has been concerned with features that are geographically confined to that place - such as a natural resource endowment or a local policy or regulation - the attention of IB research has increasingly been turning to the relevance of the extent of the translocal or global connectivity of a location with other places (Bathelt, Cantwell, \& Mudambi, 2018; Cano-Kollmann, Cantwell, Hannigan, Mudambi, $\&$ Song, 2016). Yet location advantages in this sense are not entirely exogenous to the MNC, since the external connectivity of a place is influenced by the evolution of the international network structures of firms that have operations sited there. Hence, MNCs may sometimes prefer entry modes that confer greater control over their local operations in order to have greater flexibility in the management of their overall international network, which then allows them to respond more effectively to changes in the local environment in any location (Belderbos \& Zou, 2007). The newer view of the location in IB scholarship is close to the perspective of geographers on world city networks, in which the positioning of cities is driven by what flows through them rather than by what is fixed within them (Derudder, Witlox, \& Taylor, 2007).

\section{Local-Global Interactions and the Spread of Knowledge Hubs}

It has become critical to gain a better understanding of the relationships between cities and firms in the construction of IB networks, and in the consequent emergence and evolution of global cities (Goerzen, Asmussen, \& Nielsen, 2013). In at least the largest, most technologically active cities, it has been shown that the extent of knowledge networking within the boundaries of a metropolitan area is positively associated with the extent of translocal and global knowledge networking by its residents (Cantwell \& Zaman, 2018). This suggests that agents which provide the connectivity between places may well also play an active brokerage role in interfacing between local and non-local network actors in the cities in which they are situated. It is therefore unsurprising that firms may preserve a knowledge advantage within their industry through increasing the geographic scope of their international knowledge network (Kim, 2013). Indeed, the management of knowledge diversity across local metropolitan networks may in itself help to explain the ability of MNCs to benefit from greater geographic scope (Scalera, Perri, \& Hannigan, 2018). More specifically, firms are better able 
to connect geographically distant clusters where the local and international networks have some related characteristics which facilitate new valuecreating opportunities through the cross-fertilization of networks (Choudhury, Geraghty, \& Khanna, 2012; Li \& Bathelt, 2018; Turkina \& Van Assche, 2018).

Due to the existence of cross-network knowledge interdependencies, innovation can become a positive sum game across selected areas between which ideas are interchanged (Cantwell, 2005; Harmancioglu \& Tellis, 2018). In a context in which key actors are intensively networked, either locally or globally or both, we need a holistic understanding of the behavior of the wider relational system of multiple actors of different types of which they are part (Bathelt \& Glückler, 2011). Thus, for instance, the international knowledge networks of migrants may influence the geographic structure of the cross-border mergers and acquisitions undertaken by the R\&D-intensive firms that employ skilled migrants (Useche, Miguelez, \& Lissoni, 2020).

Once we view an interlocking structure of networks as a whole for their interactions, we are likely to observe a complex geographic system with some multifaceted hierarchies, rather than a single uniform hierarchy of locations. In an earlier era, Hymer (1972) suggested a direct and simpler association between the internal organizational hierarchy of the MNC and the geography of uneven development across locations. Higher-order activities would be conducted in the most prosperous and dynamic centers, while activities with weaker potential for new value creation would be located in poorer regions, thereby reinforcing an established geographic hierarchy and restricting the scope for economic development in the periphery. Instead, in the information or digital age, geographic hierarchies are more often the outcome of the evolution of IB network structures, rather than the prior, internally confined characteristic of the functions that have been sited historically in each place (Kali \& Reyes, 2007; Lüthi, Thierstein, \& Hoyler, 2015). Although global cities may lead the way, in a knowledge-driven society there are a variety of other places besides the main urban centers in which intensive interaction occurs. Geographers consider that this spread of knowledge-based nodes has led to new forms of business networks linking locations at different spatial scales (Lüthi et al. 2015).
In Table 1, we provide an overview list of the studies that have featured in the above review, as examples that have used the network perspective in IB research at different levels.

\section{FUTURE DIRECTIONS FOR SOCIAL NETWORK RESEARCH IN IB}

Following the order of the different levels in our brief review above, in this section we touch upon some themes and research directions in less explored, recent, and ongoing work IB that leverages social network perspective and tools.

\section{Inter-personal Networks}

Left unstudied in many of the empirical and theoretical accounts of reliance on personal contacts are three areas of research relevant to IB. First, current approaches neglect the likelihood that cronyism - defined as reciprocal provision of favors - can damage organizations and communities, even as research indicates that the incidence and form of such cronyism may vary across cultures (Khatri, Tsang, \& Begley, 2006). The network perspective emphasizes that a central position in the social network can bring advantages, including faster promotions and higher salaries (Fang, Landis, Zhang, Anderson, Shaw, \& Kilduff, 2015). However, in societies with weak institutional structures, getting ahead through social network connections may involve types of influence that undermine rather than promote fairness (Begley, Khatri, \& Tsang, 2010). Social network research in international contexts should be careful to avoid promoting the practice of cronyism, even if becoming a crony is purported to be helpful to foreign managers endeavoring to gain advantages exclusive to old-friend networks (Leung, Heung, \& Wong, 2008).

Second, we know little about how the flow of energy across boundaries between key people in the MNC affects knowledge transfer, revitalizing some projects while draining others of interest (Baker, 2019). We do know that knowledge transfer within the MNC depends, in part, on the motivation and competencies of the people involved (Minbaeva, Pedersen, Bjorkman, Fey, \& Park, 2003). The underlying relationships that constitute social capital within the MNC require high investments of time and energy, given that they cross national boundaries, ethnicities, and markets (see the review of MNC social capital by Taylor, 2007). For example, strong ties facilitated knowledge transfer across 
Table 1 Overview studies for the different levels and themes in our review

\section{Inter-personal networks in international business}

\section{Embeddedness}

E.g., Coviello (2006), Newburry and Yakova (2006), Batjargal (2007), Luo (2007), Luk et al. (2008), Styles et al. (2008), Zhou et al. (2008), Chua et al. (2009), Madhavan and Iriyama (2009), Su et al. (2009), Ellis (2011), Laursen et al. (2012), Sigfusson and Chetty (2013) and Chen and Shaffer (2017)

\section{Boundary spanning}

E.g., Ellis (2000), Au and Fukuda (2002), Xiao and Tsui (2007), Li et al. (2009), Lu et al. (2010), Su et al. (2009), Johnson and Duxbury (2010), Musteen et al. (2010), Barner-Rasmussen et al. (2014), Gao et al. (2014), Burt and Burzynska (2017) and Fitzsimmons et al. (2017)

\section{Knowledge transfer}

E.g., Manev and Stevenson (2001), Carraher et al. (2008), Liu et al. (2010), Zaheer et al. (2009), Bruning et al. (2012), Tröster and van Knippenberg (2012), Levin and Barnard (2013), Morris et al. (2014), Peltokorpi and Vaara (2014), Selmier II et al. (2015), Haas and Cummings (2015), Wang (2015), Lin et al. (2016), Ang et al. (2018) and Ertug et al. (2018

\section{Conceptual and theoretical perspectives}

E.g., Money (1998), Griffith and Harvey (2004), Andersen (2006), Luo and Shenkar (2006), Oddou et al. (2009), Nebus and Rufin (2010) and Crane and Hartwell (2019)

\section{Inter-subsidiary networks in international business}

\section{Knowledge transfer and learning}

E.g., Björkman et al. (2004), Dhanaraj et al. (2004), Venaik et al. (2005), Noorderhaven and Harzing (2009), Asakawa et al. (2018) and Dau (2018)

\section{Subsidiary power, autonomy, and influence}

E.g., Mudambi and Navarra (2004), Andersson et al. (2007), Chung et al. (2010), Dörrenbächer and Gammelgaard (2010), Ambos et al. (2011), Balogun et al. (2011), Najafi-Tavani et al. (2014) and Nell et al. (2011)

\section{Performance implications of subsidiary networks}

E.g., Allen and Pantzalis (1996), Elango and Pattnaik (2007), Lee and Makhija (2009) and Scott-Kennel and Giroud (2015)

\section{Other ongoing themes and recent work}

E.g., Dimitratos et al. (2009), Khan et al. (2015) and lurkov and Benito $(2018,2020)$

\section{Inter-firm networks in international business}

\section{Interfirm network outcomes}

E.g., Westney and Sakakibara (1985), Bartlett and Ghoshal (1989), Ghoshal and Nohria (1989, 1993), Ghoshal and Bartlett (1990), Spencer (2003), Elango and Pattnaik (2007), Eapen (2012), Shi et al. (2014), Xia et al. (2018), Sharma et al. (2019) and lurkov and Benito (2020)

\section{Interfirm networks as contingencies}

E.g., Vasudeva et al. (2013) and Mingo et al. (2018)

\section{Inter-location networks in international business}

\section{International business network structures and embeddedness}

E.g., Cantwell (1989), Hedlund (1994), Nohria and Ghoshal (1997), Cantwell and lammarino (2003), Chini (2004), Monteiro et al. (2008), Cantwell (2009), Johanson and Vahlne (2009), Cantwell and Mudambi (2011), Asakawa et al. (2018), Awate and Mudambi (2018) and Li and Bathelt (2018)

\section{Connectivity across firms and places}

E.g., Rosenkopf and Almeida (2003), Belderbos and Zou (2007), Derudder et al. (2007), Vasudeva et al. (2013), Cano-Kollmann et al. (2016), Zhang and Pezeshkan (2016), Bathelt et al. (2018) and Stallkamp et al. (2018)

\section{Local-global interactions and the spread of knowledge hubs}

E.g., Hymer (1972), Cantwell (2005), Kali and Reyes (2007), Bathelt and Glückler (2011), Choudhury et al. (2012), Goerzen et al. (2013), Kim (2013), Lüthi et al. (2015), Cantwell and Zaman (2018), Harmancioglu and Tellis (2018), Li and Bathelt (2018), Scalera et al. (2018), Turkina and Van Assche (2018) and Useche et al. (2020) 
units within an MNC R\&D department (Tortoriello, Reagans, \& McEvily, 2012); within the same company, the results showed that bridging across intraorganizational boundaries with a Simmelian tie (i.e., a tie between two people who are both connected to a third person) was particularly generative of innovation (Tortoriello \& Krackhardt, 2010). These kinds of strong, bridging ties, require considerable emotional energy and commitment, and require further research attention within the IB research program.

Another surprising omission in research at the interpersonal level relates to social network brokerage, which is a vital topic for understanding the development of new ideas (Kilduff \& Lee, 2020). Social network brokers interpret and transfer knowledge across the gaps in social structure, moving ideas from one cluster to another (Burt, 1992). Recent theory has emphasized the importance of brokers spanning across structural and cultural holes in a transnational context (Levy, Lee, Jonsen, \& Peiperl, 2019). The MNC would seem to be a prime site for the importance of such brokerage at the interpersonal level, but relevant studies are lacking.

\section{Inter-subsidiary Networks}

In this sub-section, we note some recently emerging and relatively new directions that can continue to expand and deepen the integration of network thinking, mechanisms, and methods into the study of inter-subsidiary networks in IB research.

First, because most work to date has been at the dyadic level (subsidiary-HQ, for example, or, less frequently, subsidiary-subsidiary), studies that further investigate the network of subsidiaries as a whole, studies that leverage triadic arguments and mechanisms [such as in the case of Simmelian ties (Krackhardt, 1999), which have been used mostly on research on interpersonal networks, whether within or outside of IB research], or studies that consider the internal and external networks of subsidiaries (meaning consider the complete network, or ego-network, of a subsidiary, rather than focusing on the subsidiary-HQ relationship only/ exclusively), can both augment and complement the insights and findings from the dyadic work.

Second, further research on the dynamics of and the inter-relationships between the internal network (of subsidiaries) and the external network (of ties by subsidiaries to non-MNC-owned actors), for example as in Nell and Ambos (2013), would also be useful to expand our knowledge about these relatively understudied phenomena. The dynamics of multiple networks and further investigations into the emergence, evolution, and implications of multiplexity are topics that are continuing to generate interest in network research more generally.

Third, because of the prevalence of discussions about power and influence in research on intersubsidiary networks, further conceptual elaboration and refinement of the similarities and differences between power and influence, and other related concepts, such as status, would pave the way for the accumulation and compatibility of arguments and findings from different studies and different research streams that might be working with different constructs and from different perspectives. The degree to which the similarities and differences between these perspectives are discussed and clarified is likely to be one input into making findings from different streams or work more compatible with each other and more accumulative together.

Fourth, given the earlier interest in network forms of organization and hybrid organizations (Powell, 1990), as well as arguments about both the advantages and drawbacks of embeddedness (Uzzi, 1997) and trust (Gargiulo \& Ertug, 2006), there are also fruitful avenues to explore regarding the governance of subsidiary networks, both with respect to the network mechanisms we reference above and their joint consideration with better established perspectives in this literature, such as transaction cost theory (TCE) and agency theory.

\section{Global Inter-firm Networks}

Although we see an uptick in the very recent past in IB research that uses the global interfirm network perspective, considerable opportunities remain.

\section{Network antecedents}

The antecedents of global networks at the interfirm level, both ego networks (i.e., the network is a single firm) and 'whole' networks (the network structure of all the firms in an industry) continue to be poorly understood. Of course, some of the literature in the alliances domain has explored why and when alliances and alliance networks form in general terms, but understanding why they take the shape and structure that they do in global settings would represent an interesting direction. Given the inevitable 'so what?' question, the global 
network structures being explained should be ones that are well known to hold implications for firm performance, such as global structural holes.

\section{'Born global' networks}

Buyer-supplier and ego alliance networks of firms of the 'born global' variety have seen little attention from scholars adopting a network perspective. As an increasing number of young, entrepreneurial firms venture globally, not through the step-by-step approach of the Uppsala model of internationalization but rather all at once, IB researchers have an opportunity to explore the network processes that enable the 'born global' phenomenon and why and how it presents such a contrast to the Uppsala model.

\section{Networks and global contingencies}

Country differences, such as in national culture and its distance, national trust and its distance, and national institutions, among many other countrylevel differences and distances, may serve as contingencies in the operations of networks and networks structures (e.g., Vasudeva et al., 2013). For example, distant national cultures may impede the formation of an alliance tie between firms A and B, who might each have a tie with a third country firm $\mathrm{C}$, making it a broker. Moreover, brokerage may persist longer because of cultural distance between the countries in which firms A and B are located.

\section{Evolutionary patterns in global interfirm networks}

More recently, network research has focused on the dynamic evolutionary patterns exhibited by networks (Ahuja, Soda, \& Zaheer, 2012). This vein of network research also holds considerable promise for IB. In particular, as broader global trade tensions roil the markets, prospects for cross-national interfirm relationships for MNCs are also likely to be affected. A fruitful area of enquiry might study how an MNC's global networks track the evolving patterns of trade flows, whether constraining or facilitating or even reconfiguring an MNC's patterns of global outreach.

\section{Inter-location Networks}

There are various directions for new research in which the work of IB scholars and economic geographers on networks might be brought closer together.

It has been commonplace in economic geography to analyze the geographic structure of business networks in terms of hub and spoke locations, such as in discussions of flight patterns in the airline industry, and explanations for the shifting configuration of international airline alliances, each with their own specific selection of airport hubs. In contrast, IB scholars have often worked with a simpler dualistic distinction between a hub-andspoke MNC subsidiary structure characterized by a single hub (the parent company in the home country) by comparison with a more integrated or denser MNC network structure (see, e.g., Bartlett \& Ghoshal, 1989). Yet, as suggested by Monteiro et al. (2008), the so-called integrated MNC subsidiary network structure is likely to be one that has multiple hubs, rather like in the airline industry. In other words, an MNC with a more complex network structure generally has a selection of subsidiaries in particular locations that occupy central network positions for the MNC, apart from the parent company in the home location. Therefore, we need to better understand the international geography of MNC network structures in cases in which MNCs depart from a simpler huband-spoke structure around the parent company as their only major hub. While the distinction between a home region focus and a more geographically globally dispersed array of MNC operations may remain relevant here, describing and examining different kinds of international MNC network structures across locations can and should reach well beyond this starting point.

Geographers now also often study world city networks through their firm-level connections (Taylor \& Derudder, 2016), and they emphasize especially the role of producer service firms as agents that help to facilitate and create city-to-city IB networks (Sassen, 2005). However, IB researchers are very well placed to examine questions that ask either how the geography of networks have been driven by the connections built by some particular MNCs that operate in certain network nodes, or, the other way around, how firms have responded to the increasing or diminishing international connectivity of a place over time. We should also be able to investigate which kinds of firms are more likely to act as brokers or otherwise facilitate the growth of IB networks, and the conditions under which firms can transition from positions of outsidership to insidership within different kinds of such networks. We need to know more about how network-influencing firms can affect the relative degrees of openness or closure of networks to MNC activities, and how MNE network connections interface with the capacity for an increased reach 
by local networks in the places in which MNCs operate.

In general, it seems quite likely that the ability of cities to attract certain kinds of MNC activity depends upon the nature of cross-network interdependencies within a city. For example, Shaver (2018) has shown how the success of Minneapolis-St. Paul as a headquarters location depended upon the ability of managers to move relatively freely between industries, unlike in many other cities, since cross-industry network connections within the city have been comparatively strong. Therefore, the kinds of network associations that the same MNC can make are likely to vary from one location to another, which may in turn influence its own inter-locational network structure. We would like a better understanding of how different networks interact within and between locations, and how this may affect the ability of urban areas to shift the composition of their economic specialization over time.

It would also be interesting to know more about the circumstances under which the international network connectivity of a city is dependent on a few dominant leader firms active in a location, or is instead the outcome of the structure of linkages developed by a wide diversity of firms and other actors. We have evidence already that cities which have become more internationally connected have also tended to grow faster, increase incomes, and sustain a better quality of life for residents (Cantwell \& Zaman, 2018; Storper, 2018). Beyond the identity of the leading actors, further research would be valuable on the kinds of contributory MNC-level factors that have tended to drive the rise or fall in the network centrality of cities in particular industries, or in the extent of geographic concentration of particular kinds of IB activity that are conducted in spatially dispersed networks.

In Table 2, we provide some examples of the research opportunities discussed above.

\section{PAPERS IN THE SPECIAL ISSUE}

The above review illustrates the value of drawing from the social network perspective to advance research on IB. However, it also makes it clear that there is considerable potential for future research. The aim of our special issue is to highlight this potential. The five accepted papers illustrate this and tap into that potential. Here, we provide a brief summary of the key insights and contributions of these papers (ordered by the level of analysis).
Useche et al. (2020) focus on migrant networks. Their study is the only one in this special issue that focuses on individual-level networks. Migration has become an important theme in IB research and is a point of active debate in many societies across the world. This study looks at the role of migrant inventors in cross-border mergers and acquisitions undertaken by R\&D-active firms, and proposes that these acquirers can benefit from the international social network of their migrant inventors. Specifically, inventors' social networks can help acquirers to identify and/or integrate relevant knowledge about acquisition targets in the inventors' home country. As a result, migrant inventors can affect their companies' choice of cross-border targets by increasing the probability of the target to be located in the inventor's country of origin. The authors also propose a number of contingency factors that are integral to IB, such as the distance between the acquirer and the potential target, and the quality of institutions in the potential host country. This study adds to a growing body of IB research that emphasizes the role of ethnic ties in MNCs' location choices (e.g., Hernandez, 2014; Zaheer et al., 2009) and further advances our understanding when such ties might matter more.

The next three studies look primarily at interfirm networks. Gözübüyük, Kock, and Ünal's (2020) study investigates how country-level institutions affect who lays claim to rents from centrality in interfirm networks. To explore this issue, the authors use the context of the Islamic finance industry, in which they focus on the interlocking network of Shariah scholars on firms' Shariah boards. They find that the legitimization and information benefits to firms from having wellconnected central Shariah scholars on these boards are more than offset by information leakage across firms and the lower attention the busy central scholars can devote to the firm. However, the negative financial consequences of relying on a few central Shariah scholars vary across countries, depending on the quality of the institutions and regulatory regime, such that, in countries with strong institutions, firms may still benefit from hiring central scholars to be on their boards. By showing that the institutional context affects the benefits that actors receive and the costs that they incur from their centrality in social elite networks, this study highlights the importance of incorporating the institutional context in social network studies. 
Table 2 Directions for future research

\begin{tabular}{|c|c|c|c|}
\hline Inter-personal networks & Inter-subsidiary networks & Inter-firm networks & Inter-location networks \\
\hline $\begin{array}{l}\text { More investigation into how } \\
\text { the effects of cronyism might } \\
\text { vary across countries, and how } \\
\text { cronyism can damage } \\
\text { organizations and communities } \\
\text { Studying how the flow of } \\
\text { energy (see Baker, 2019) } \\
\text { across boundaries between } \\
\text { key people in the MNC affects } \\
\text { knowledge transfer } \\
\text { More exploration of how social } \\
\text { network brokers, who } \\
\text { interpret and transfer } \\
\text { knowledge across the gaps in } \\
\text { social structure, play a role } \\
\text { within MNCs }\end{array}$ & $\begin{array}{l}\text { In addition to dyadic level } \\
\text { research (e.g., subsidiary-HQ), } \\
\text { also considering the network of } \\
\text { subsidiaries as a whole, if not } \\
\text { also approaches that consider } \\
\text { triads } \\
\text { The dynamics and inter- } \\
\text { relationships between the } \\
\text { internal network (of } \\
\text { subsidiaries) and the external } \\
\text { network (of ties by } \\
\text { subsidiaries to non-MNC- } \\
\text { owned actors) } \\
\text { Further exploring the } \\
\text { governance of subsidiary } \\
\text { networks with respect to } \\
\text { embeddedness and trust, as } \\
\text { well as their consideration } \\
\text { together with other } \\
\text { governance perspectives, } \\
\text { such as TCE and agency } \\
\text { theory } \\
\text { Further discussion and } \\
\text { clarification of the similarities } \\
\text { and differences between } \\
\text { power and influence, and } \\
\text { other cognate concepts }\end{array}$ & $\begin{array}{l}\text { Improving our understanding } \\
\text { of the antecedents, shape, and } \\
\text { structure of global networks at } \\
\text { the interfirm level } \\
\text { Investigating the buyer- } \\
\text { supplier and ego alliance } \\
\text { networks "born global" firms } \\
\text { Exploring in more detail how } \\
\text { country differences in formal } \\
\text { and informal institutions may } \\
\text { serve as contingencies in the } \\
\text { operations of networks and } \\
\text { networks structures }\end{array}$ & $\begin{array}{l}\text { Examining world city networks } \\
\text { by specifically looking at the } \\
\text { connections built by particular } \\
\text { MNEs that operate as certain } \\
\text { network nodes, as well as how } \\
\text { firms respond to the increasing } \\
\text { or diminishing international } \\
\text { connectivity of a place over } \\
\text { time } \\
\text { Further investigation into what } \\
\text { kinds of firms are more likely } \\
\text { to act as brokers or otherwise } \\
\text { facilitate the growth of } \\
\text { international business } \\
\text { networks, and the conditions } \\
\text { under which firms can } \\
\text { transition from positions of } \\
\text { outsidership to insidership } \\
\text { within different kinds of } \\
\text { international networks } \\
\text { Exploring the circumstances } \\
\text { under which the international } \\
\text { network connectivity of a city } \\
\text { is dependent on a few } \\
\text { dominant leader firms active } \\
\text { in a location, or is instead the } \\
\text { outcome of the structure of } \\
\text { linkages developed by a wide } \\
\text { diversity of firms and other } \\
\text { actors }\end{array}$ \\
\hline
\end{tabular}

\section{Multi-level and inter-level research}

More systematically considering the relationships and interplay between networks at two (or more) levels of analysis to explain IB phenomenon

The study by Iurkov and Benito (2020) explores how domestic interfirm networks affect MNCs' foreign divestment decisions. The authors argue and find that, as firms become more central in their domestic network, they are more likely to divest some of their foreign operations. This effect seems to be more pronounced when a firm faces higher levels of firm-specific uncertainty and domestic market uncertainty. This work extends the literature on the role that firms' embeddedness in interfirm networks plays for their internationalization. Specifically, while prior work has primarily seen interfirm networks and embeddedness as a driver of international expansion, this study shows that interfirm networks may also result in international contraction through divestments, rather than expansion.
The article by Shijaku, Larraza-Kintana, and Urtasun-Alonso (2020) improves our understanding of how a firm's structural positioning, and in particular its network centrality, affects the role of aspirations. More specifically, the study starts by exploring how a firm's network centrality affects its internationalization behavior in terms of the number of its international alliances and how distant are its alliance partners. Subsequently, the focus shifts towards how being above or below aspirations affects these same two outcomes. Finally, the authors bridge the network and aspiration aspects of their study and look at how network centrality moderates the effects of being above or below aspirations. Using a sample of firms in the global pharmaceutical industry, the authors find evidence of this conjoint effect of performance feedback and network centrality on international alliance 
formation. The main contribution of this study lies in the fruitful integration of the social network and behavioral perspectives of firm behavior to explain the formation of international alliances.

In addition to the previous studies, which are primarily at the individual or firm level, we also have a study at the country level. Cannizzaro's (2020) study advances the MNC-host country relationships literature using a network approach at the country level to explain MNC behavior. The author starts from an existing theoretical model by Nebus and Rufin (2010), which focuses on MNC bargaining influence (measured as network centrality), and expands it to incorporate the effect of social influence (measured using structural equivalence) to explain MNC sensitivity to political risk. Using a transaction-level dataset from the global petroleum industry, and network measures based on countries' trade relationships, the author finds mixed empirical results: The results support the idea that social influence attenuates the negative effect of host-country political risk on MNCs' transparency, particularly for non-state-owned firms. However, in this empirical context, the findings do not support some of the core insights of Nebus and Rufin's (2010) theoretical model of MNC bargaining power. This study makes a contribution by demonstrating the promise of investigating networks at the country level, and, in part due to its mixed results, also raises intriguing questions for future research.

These five studies show the rewards of drawing from the social network perspective to address important IB phenomena at different levels of analysis. While our special issue includes studies at the individual, firm and country level, with some that touch upon more than one level in their arguments and mechanisms, we do not have a study investigating inter-subsidiary networks. This by no means suggests a lack of potential at this level of analysis. Prior work that has looked at intersubsidiary networks (e.g., Mudambi \& Navarra, 2004; Andersson et al., 2007; Nell et al., 2011) has offered many valuable insights, as we also further touched upon in our corresponding review earlier, and there clearly remains substantial potential (as we note in the future research section) to make further advances.

\section{CONCLUSIONS}

The social network perspective has played a prominent role in sociology. It has also yielded important advances in economics, psychology, and interdisciplinary research. The presence of the social network perspective in IB research has remained more limited by comparison. Nevertheless, there is a growing body of work in IB that has offered valuable insights by taking a network perspective. We provided a brief overview of this body of work, to give a sense of some of the ongoing themes and recent directions that investigate IB-related phenomena at different levels which use network arguments, measures, or methodology. We hope that our overview and discussion provides a convincing sense of the rewards from applying social network theories and methods in IB research. The kinds of contributions we have in mind are illustrated by the five papers in this special issue.

In addition to the examples of research opportunities we touched upon, we also note that there is potential for multi-level and inter-level research in IB. IB research typically embraces the multi-level aspects of phenomena and often considers additional levels of analysis, such as the country or region, than is typical in non-IB work (e.g., Peterson, Arregle, \& Martin, 2012). Hence, IB research might be particularly well suited to take a multilevel or inter-level network perspective, which might enable them to offer advances to the broader network literature, and also make good use of recent conceptual and methodological advances in that literature. While there might be several ways to leverage this potential in studying IB-related issues, one way could be to investigate the relationships and interplay between networks at two (or more) levels of analysis to explain IB phenomena. For example, future research could locate interpersonal networks within the larger context of nations and study the effect of potential linkages between these two levels on IB phenomena. Hence, we hope to not only stimulate network research within each of the different levels of analysis we covered but to also encourage multi-level and inter-level research.

\section{ACKNOWLEDGEMENTS}

The authors would like to thank Bjorn Ambos, Tina Ambos, Gabriel Benito, Hans Frankort, Exequiel (Zeke) Hernandez, Niels Noorderhaven, and Senior Editor Yadong Luo for their comments. Errors are ours. All authors contributed equally to the manuscript. 


\section{NOTES}

${ }^{1}$ Some studies focus on multiple levels. We cover such studies at the level for which we think they are most relevant, and in some cases the same study might be discussed in more than one section, for different levels of analysis. To highlight the importance of these multi-level or inter-level studies, we discuss the implication of such research at the end of our review.

${ }^{2}$ We include some work on international joint ventures (IJVs) in this section. It is true that, unlike the case for subsidiaries, headquarters typically do not have complete control over joint ventures.

\section{REFERENCES}

Ahuja, G. 2000. Collaboration networks, structural holes, and innovation: A longitudinal study. Administrative Science Quarterly, 45(3): 425-455.

Ahuja, G., Soda, G., \& Zaheer, A. 2012. The genesis and dynamics of organizational networks. Organization Science, 23(2): 434-448.

Allen, L., \& Pantzalis, C. 1996. Valuation of the operating flexibility of multinational corporations. Journal of International Business Studies, 27(4): 633-653.

Ambos, B., Asakawa, K., \& Ambos, T. C. 2011. A dynamic perspective on subsidiary autonomy. Global Strategy Journal, 1(3-4): 301-316.

Andersen, P. H. 2006. Listening to the global grapevine: SME export managers' personal contacts as a vehicle for export information generation. Journal of World Business, 41(1): 81-96.

Andersson, U., Forsgren, M., \& Holm, U. 2001. Subsidiary embeddedness and competence development in MNCs - A multi-level analysis. Organization Studies, 22(6): 1013-1034.

Andersson, U., Forsgren, M., \& Holm, U. 2007. Balancing subsidiary influence in the federative MNC: A business network view. Journal of International Business Studies, 38(5): 802-818.

Andersson, U., Forsgren, M., \& Pedersen, T. 2001. Subsidiary performance in multinational corporations: The importance of technology embeddedness. International Business Review, 10(1): 3-13.

Ang, S. H., Benischke, M. H., \& Hooi, A. W. L. 2018. Frequency of international expansion through high control market expansion modes and interlocked directorships. Journal of World Business, 53(4): 493-503.

Asakawa, K., Park, Y., Song, J., \& Kim, S. J. 2018. Internal embeddedness, geographic distance, and global knowledge sourcing by overseas subsidiaries. Journal of International Business Studies, 49: 743-752.

Au, K. Y., \& Fukuda, J. 2002. Boundary spanning behaviors of expatriates. Journal of World Business, 37(4): 285-296.

Awate, S., \& Mudambi, R. 2018. On the geography of emerging industry technological networks: The breadth and depth of patented innovations. Journal of Economic Geography, 18(2): 391-419.

Baker, W. E. 2019. Emotional energy, relational energy, and organizational energy: Toward a multilevel model. Annual Review of Organizational Psychology and Organizational Behavior, 6: 373-395.

Balogun, J., Jarzabkowski, P., \& Vaara, E. 2011. Selling, resistance and reconciliation: A critical discursive approach
However, because the mechanisms or arguments were similar in some cases, we chose to touch upon some studies here that study IJVs, rather than subsidiaries as such.

${ }^{3}$ In a separate, but related, study, Iurkov and Benito (2020) use data from 274 publicly traded firms between 2000 and 2008 in the ICT industry to explore the implications of the betweenness centrality of a firm in its domestic (home country) interfirm network for its foreign divestment decisions.

to subsidiary role evolution in MNEs. Journal of International Business Studies, 42(6): 765-786.

Barabasi, L. 2002. Linked. London: Penguin.

Barner-Rasmussen, W., Ehrnrooth, M., Koveshnikov, A., \& Mäkelä, K. 2014. Cultural and language skills as resources for boundary spanning within the MNC. Journal of International Business Studies, 45(7): 886-905.

Bartlett, C. A., \& Ghoshal, S. 1989. The transnational solution. Boston: Harvard Business School.

Bathelt, H., Cantwell, J. A., \& Mudambi, R. 2018. Overcoming frictions in transnational knowledge flows: challenges of connecting, sense-making and integrating. Journal of Economic Geography, 18(5): 1001-1022.

Bathelt, H., \& Glückler, J. 2011. The relational economy: Geographies of knowing and learning. Oxford: Oxford University Press.

Batjargal, B. 2007. Network triads: Transitivity, referral and venture capital decisions in China and Russia. Journal of International Business Studies, 38(6): 998-1012.

Begley, T. M., Khatri, N., \& Tsang, E. W. 2010. Networks and cronyism: A social exchange analysis. Asia Pacific Journal of Management, 27(2): 281-297.

Belderbos, R., \& Zou, J. 2007. On the growth of foreign affiliates: Multinational plant networks, joint ventures, and flexibility. Journal of International Business Studies, 38: 1095-1112.

Björkman, I., Barner-Rasmussen, W., \& Li, L. 2004. Managing knowledge transfer in MNCs: The impact of headquarters control mechanisms. Journal of International Business Studies, 35(5): 443-455.

Bruning, N. S., Sonpar, K., \& Wang, X. 2012. Host-country national networks and expatriate effectiveness: A mixedmethods study. Journal of International Business Studies, 43(4): 444-450.

Burt, R. S. 1992. Structural holes. Cambridge: Harvard University Press.

Burt, R. S. 2005. Brokerage and closure: An introduction to social capital. Oxford: Oxford University Press.

Burt, R. S., \& Burzynska, K. 2017. Chinese entrepreneurs, social networks, and guanxi. Management and Organization Review, 13(2): 221-260.

Burt, R. S., Kilduff, M., \& Tasselli, S. 2013. Social network analysis: Foundations and frontiers of advantage. Annual Review of Psychology, 64: 527-547.

Cannizzaro, A. 2020. Social influence and MNE strategic response to political risk: A global network approach. Journal of International Business Studies. https://doi.org/10.1057/ s41267-019-00246-4. 
Cano-Kollmann, M., Cantwell, J. A., Hannigan, T. J., Mudambi, R., \& Song, J. 2016. Knowledge connectivity: An agenda for innovation research in international business. Journal of International Business Studies, 47(3): 255-262.

Cantwell, J. A. 1989. Technological innovation and multinational corporations. Oxford: Blackwell.

Cantwell, J. A. 2005. Innovation and competitiveness. In I. Fagerberg, D. C. Mowery, \& R. R. Nelson (Eds), The Oxford handbook of innovation. Oxford: Oxford University Press.

Cantwell, J. A. 2009. Location and the multinational enterprise. Journal of International Business Studies, 40(1): 35-41.

Cantwell, J. A., \& lammarino, S. 2003. Multinational corporations and European regional systems of innovation. London: Routledge.

Cantwell, J. A., \& Mudambi, R. 2011. Physical attraction and the geography of knowledge sourcing in multinational enterprises. Global Strategy Journal, 1(3-4): 206-232.

Cantwell, J. A., \& Zaman, S. 2018. Connecting local and global technological knowledge sourcing. Competitiveness Review, 28(3): 277-294.

Carnabuci, G., \& Diószegi, B. 2015. Social networks, cognitive style, and innovative performance: A contingency perspective. Academy of Management Journal, 58(3): 881-905.

Carraher, S. M., Sullivan, S. E., \& Crocitto, M. M. 2008. Mentoring across global boundaries: An empirical examination of home- and host-country mentors on expatriate career outcomes. Journal of International Business Studies, 39(8): 1310-1326.

Chen, Y. P., \& Shaffer, M. A. 2017. The influences of perceived organizational support and motivation on self-initiated expatriates' organizational and community embeddedness. Journal of World Business, 52(2): 197-208.

Cheong, A., Sandhu, M. S., Edwards, R., \& Poon, W. C. 2019. Subsidiary knowledge flow strategies and purpose of expatriate assignments. International Business Review, 28(3): 450-462.

Chini, T. C. [later: Ambos, T.C.] 2004. Effective knowledge transfer in multinational corporations. London: Palgrave Macmillan.

Choudhury, P., Geraghty, J. A., \& Khanna, T. 2012. A 'coreperiphery' framework to navigate emerging market governments - Qualitative evidence from a biotechnology multinational. Global Strategy Journal, 2: 71-87.

Christakis, N. A., \& Fowler, J. H. C. 2009. The surprising power of our social networks and how they shape our lives. New York: Little Brown.

Chua, R. Y., Morris, M. W., \& Ingram, P. 2009. Guanxi versus networking: Distinctive configurations of affect-and cognitionbased trust in the networks of Chinese versus American managers. Journal of International Business Studies, 40(3): 490-508.

Chung, C. C., Lee, S. H., Beamish, P. W., \& Isobe, T. 2010. Subsidiary expansion/contraction during times of economic crisis. Journal of International Business Studies, 41(3): 500-516.

Coviello, N. E. 2006. The network dynamics of international new ventures. Journal of International Business Studies, 37(5): 713-731.

Crane, B., \& Hartwell, C. J. 2019. Global talent management: A life cycle view of the interaction between human and social capital. Journal of World Business, 54(2): 82-92.

Dau, L. A. 2018. Contextualizing international learning: The moderating effects of mode of entry and subsidiary networks on the relationship between reforms and profitability. Journal of World Business, 53(3): 403-414.

Derudder, B., Witlox, F., \& Taylor, P. J. 2007. U.S. cities in the world city network: Comparing their positions using global origins and destinations of airline passengers. Urban Geography, 28(1): 74-91.

Dhanaraj, C. 2007. Managing the embedded multinational: A business network view. Journal of International Business Studies, 38(7): 1231-1233.
Dhanaraj, C., Lyles, M. A., Steensma, H. K., \& Tihanyi, L. 2004. Managing tacit and explicit knowledge transfer in IJVs: The role of relational embeddedness and the impact on performance. Journal of International Business Studies, 35(5): 428-442.

Dimitratos, P., Liouka, I., \& Young, S. 2009. Regional location of multinational corporation subsidiaries and economic development contribution: Evidence from the UK. Journal of World Business, 44(2): 180-191.

Dörrenbächer, C., \& Gammelgaard, J. 2010. Multinational corporations, inter-organizational networks and subsidiary charter removals. Journal of World Business, 45(3): 206-216.

Eapen, A. 2012. Social structure and technology spillovers from foreign to domestic firms. Journal of International Business Studies, 43(3): 244-263.

Elango, B., \& Pattnaik, C. 2007. Building capabilities for international operations through networks: A study of Indian firms. Journal of International Business Studies, 38(4): 541-555.

Ellis, P. 2000. Social ties and foreign market entry. Journal of International Business Studies, 31(3): 443-469.

Ellis, P. D. 2011. Social ties and international entrepreneurship: Opportunities and constraints affecting firm internationalization. Journal of International Business Studies, 42(1): 99-127.

Ertug, G., Gargiulo, M., Galunic, C., \& Zou, T. 2018. Homophily and individual performance. Organization Science, 29(5): 912-930.

Fang, R., Landis, B., Zhang, Z., Anderson, M. H., Shaw, J. D., \& Kilduff, M. 2015. Integrating personality and social networks: A meta-analysis of personality, network position, and work outcomes in organizations. Organization Science, 26(4): 1243-1260.

Fitzsimmons, S. R., Liao, Y., \& Thomas, D. C. 2017. From crossing cultures to straddling them: An empirical examination of outcomes for multicultural employees. Journal of International Business Studies, 48(1): 63-89.

Forsgren, M. 2016. A note on the revisited Uppsala internationalization process model - The implications of business networks and entrepreneurship. Journal of International Business Studies, 47(9): 1135-1144.

Forsgren, M., Holm, U., \& Johanson, J. 2005. Managing the embedded multinational: A business network view. Cheltenham: Edward Elgar.

Gao, H., Knight, J. G., Yang, Z., \& Ballantyne, D. 2014. Toward a gatekeeping perspective of insider-outsider relationship development in China. Journal of World Business, 49(3): 312-320.

Gargiulo, M., \& Ertug, G. 2006. The dark side of trust. In R. Bachmann \& A. Zaheer (Eds), Handbook of trust research, 165-186. Cheltenham: Edward Elgar.

Gargiulo, M., Ertug, G., \& Galunic, C. 2009. The two faces of control: Network closure and individual performance among knowledge workers. Administrative Science Quarterly, 54(2): 299-333.

Ghoshal, S., \& Bartlett, C. A. 1990. The multinational corporation as an interorganizational network. Academy of Management Review, 15(4): 603-626.

Ghoshal, S., \& Nohria, N. 1989. Internal differentiation within multinational corporations. Strategic Management Journal, 10(4): 323-337.

Ghoshal, S., \& Nohria, N. 1993. Horses for courses: Organizational forms for multinational corporations. MIT Sloan Management Review, 34(2): 23.

Goerzen, A., Asmussen, C. G., \& Nielsen, B. B. 2013. Global cities and multinational enterprise location strategy. Journal of International Business Studies, 44: 427-450.

Gözübüyük, R., Kock, C. J., \& Ünal, M. 2020. Who appropriates centrality rents? The role of institutions in regulating social networks in the global Islamic finance industry. Journal of International Business Studies. https://doi.org/10.1057/ s41267-018-0202-4 
Granovetter, M. 1985. Economic action and social structure: The problem of embeddedness. American Journal of Sociology, 91(3): 481-510.

Griffith, D. A., \& Harvey, M. G. 2004. The influence of individual and firm level social capital of marketing managers in a firm's global network. Journal of World Business, 39(3): 244-254.

Gulati, R., \& Gargiulo, M. 1999. Where do interorganizational networks come from? American Journal of Sociology, 104(5): 1439-1493.

Gulati, R., Nohria, N., \& Zaheer, A. 2000. Strategic networks. Strategic Management Journal, 21(3): 203-215.

Haas, M. R., \& Cummings, J. N. 2015. Barriers to knowledge seeking within MNC teams: Which differences matter most? Journal of International Business Studies, 46(1): 36-62.

Harmancioglu, N., \& Tellis, G. J. 2018. Silicon envy: How global innovation clusters hurt or stimulate each other across developed and emerging markets. Journal of International Business Studies, 49: 902-918.

Hedlund, G. 1994. The hypermodern MNC: A heterarchy? Human Resource Management, 25(1): 9-35.

Heidenreich, M. 2012. The social embeddedness of multinational companies: A literature review. Socio-Economic Review, 10(3): 549-579.

Hernandez, E. 2014. Finding a home away from home: Effects of immigrants on firms' foreign location choice and performance. Administrative Science Quarterly, 59(1): 73-108.

Hymer, S. 1972. The multinational corporation and the law of uneven development. In J. Bhagwati (Ed), Economics and world order from the 1970s to the 1990s. London: Collier-Macmillan.

lurkov, V., \& Benito, G. R. G. 2018. Domestic alliance networks and regional strategies of MNEs: A structural embeddedness perspective. Journal of International Business Studies, 49(8): 1033-1059.

lurkov, V., \& Benito, G. R. G. 2020. Change in domestic network centrality, uncertainty, and the foreign divestment decisions of firms. Journal of International Business Studies. https://doi.org/ 10.1057/s41267-018-0194-0.

Jackson, M. O. 2008. Social and economic networks. Princeton: Princeton University Press.

Johanson, J., \& Vahlne, J. E. 1977. The internationalization process of the firm - A model of knowledge development and increasing foreign market commitments. Journal of International Business Studies, 8(1): 23-32.

Johanson, J., \& Vahlne, J.-E. 2009. The Uppsala internationalization process model revisited: From liability of foreignness to liability of outsidership. Journal of International Business Studies, 40(9): 1411-1431.

Johnson, K. L., \& Duxbury, L. 2010. The view from the field: A case study of the expatriate boundary-spanning role. Journal of World Business, 45(1): 29-40.

Kali, R., \& Reyes, J. 2007. The architecture of globalization: A network approach to international economic integration. Journal of International Business Studies, 38: 595-620.

Khan, Z., Lew, Y. K., \& Sinkovics, R. R. 2015. International joint ventures as boundary spanners: Technological knowledge transfer in an emerging economy. Global Strategy Journal, 5(1): 48-68.

Khatri, N., Tsang, E. W., \& Begley, T. M. 2006. Cronyism: A cross-cultural analysis. Journal of International Business Studies, 37(1): 61-75.

Kilduff, M., \& Brass, D. J. 2010. Organizational social network research: Core ideas and key debates. The Academy of Management Annals, 4(1): 317-357.

Kilduff, M., \& Lee, J. W. 2020. The integration of people and networks. Annual Review of Organizational Psychology and Organizational Behavior, 7: 155-179.

Kim, M. 2013. Many roads lead to Rome: Implications of geographic scope as a source of isolating mechanisms. Journal of International Business Studies, 44: 898-921.
Kostova, T., Marano, V., \& Tallman, S. 2016. Headquarterssubsidiary relationships in MNCs: Fifty years of evolving research. Journal of World Business, 51(1): 176-184.

Krackhardt, D. 1999. The ties that torture: Simmelian tie analysis in organizations. Research in the Sociology of Organizations, 16(1): 183-210.

Laursen, K., Masciarelli, F., \& Prencipe, A. 2012. Regions matter: How localized social capital affects innovation and external knowledge acquisition. Organization Science, 23(1): 177-193.

Lee, S. H., \& Makhija, M. 2009. The effect of domestic uncertainty on the real options value of international investments. Journal of International Business Studies, 40(3): 405-420.

Leung, T. K. P., Heung, V. C., \& Wong, Y. H. 2008. One possible consequence of guanxi for an insider: How to obtain and maintain it? European Journal of Marketing, 42(1/2): 23-34.

Levin, D. Z., \& Barnard, H. 2013. Connections to distant knowledge: Interpersonal ties between more-and less-developed countries. Journal of International Business Studies, 44(7): 676-698.

Levy, O., Lee, H. J., Jonsen, K., \& Peiperl, M. A. 2019. Transcultural brokerage: The role of cosmopolitans in bridging structural and cultural holes. Journal of Management, 45(2): $417-450$.

Li, J. J., Zhou, K. Z., \& Shao, A. T. 2009. Competitive position, managerial ties, and profitability of foreign firms in China: An interactive perspective. Journal of International Business Studies, 40(2): 339-352.

Li, P., \& Bathelt, H. 2018. Location strategy in cluster networks. Journal of International Business Studies, 49: 967-989.

Lin, D., Lu, J., Liu, X., \& Zhang, X. 2016. International knowledge brokerage and returnees' entrepreneurial decisions. Journal of International Business Studies, 47(3): 295-318.

Liu, X., Lu, J., Filatotchev, I., Buck, T., \& Wright, M. 2010. Returnee entrepreneurs, knowledge spillovers and innovation in high-tech firms in emerging economies. Journal of International Business Studies, 41(7): 1183-1197.

Lu, Y., Zhou, L., Bruton, G., \& Li, W. 2010. Capabilities as a mediator linking resources and the international performance of entrepreneurial firms in an emerging economy. Journal of International Business Studies, 41(3): 419-436.

Luk, C. L., Yau, O. H., Sin, L. Y., Alan, C. B., Chow, R. P., \& Lee, J. S. 2008. The effects of social capital and organizational innovativeness in different institutional contexts. Journal of International Business Studies, 39(4): 589-612.

Luo, Y. 2007. An integrated anti-opportunism system in international exchange. Journal of International Business Studies, 38(6): 855-877.

Luo, Y., \& Shenkar, O. 2006. The multinational corporation as a multilingual community: Language and organization in a global context. Journal of International Business Studies, 37(3): 321-339.

Lüthi, S., Thierstein, A., \& Hoyler, M. 2015. The world city network: National versus global perspective. Paper presented at the European Regional Science Association Congress, Lisbon.

Madhavan, R., \& Iriyama, A. 2009. Understanding global flows of venture capital: Human networks as the "carrier wave" of globalization. Journal of International Business Studies, 40(8): 1241-1259.

Manev, I. M., \& Stevenson, W. B. 2001. Nationality, cultural distance, and expatriate status: Effects on the managerial network in a multinational enterprise. Journal of International Business Studies, 32(2): 285-303.

Minbaeva, D., Pedersen, T., Björkman, I., Fey, C. F., \& Park, H. J. 2003. MNC knowledge transfer, subsidiary absorptive capacity, and HRM. Journal of International Business Studies, 34(6): 586-599.

Mingo, S., Morales, F., \& Dau, L. A. 2018. The interplay of national distances and regional networks: Private equity investments in emerging markets. Journal of International Business Studies, 49(3): 371-386. 
Money, R. B. 1998. International multilateral negotiations and social networks. Journal of International Business Studies, 29(4): 695-710.

Monteiro, L. F., Arvidsson, N., \& Birkinshaw, J. 2008. Knowledge flows within multinational corporations: Explaining subsidiary isolation and its performance implications. Organization Science, 19(1): 90-107.

Morris, S., Hammond, R., \& Snell, S. 2014. A microfoundations approach to transnational capabilities: The role of knowledge search in an ever-changing world. Journal of International Business Studies, 45(4): 405-427.

Mudambi, R., \& Navarra, P. 2004. Divisional power, intra-firm bargaining and rent-seeking behavior in multidivisional corporations. Economics Bulletin, 4(13): 1-10.

Musteen, M., Francis, J., \& Datta, D. K. 2010. The influence of international networks on internationalization speed and performance: A study of Czech SMEs. Journal of World Business, 45(3): 197-205.

Najafi-Tavani, Z., Giroud, A., \& Andersson, U. 2014. The interplay of networking activities and internal knowledge actions for subsidiary influence within MNCs. Journal of World Business, 49(1): 122-131.

Nebus, J., \& Rufin, C. 2010. Extending the bargaining power model: Explaining bargaining outcomes among nations, MNEs, and NGOs. Journal of International Business Studies, 41(6): 996-1015.

Nell, P. C., \& Ambos, B. 2013. Parenting advantage in the MNC: An embeddedness perspective on the value added by headquarters. Strategic Management Journal, 34(9): 1086-1103.

Nell, P. C., Ambos, B., \& Schlegelmilch, B. B. 2011. The MNC as an externally embedded organization: An investigation of embeddedness overlap in local subsidiary networks. Journal of World Business, 46(4): 497-505.

Newburry, W., \& Yakova, N. 2006. Standardization preferences: A function of national culture, work interdependence and local embeddedness. Journal of International Business Studies, 37(1): 44-60.

Nohria, N., \& Ghoshal, S. 1997. The differentiated network: Organizing multinational corporations for value creation. San Francisco: Jossey-Bass.

Noorderhaven, N., \& Harzing, A. W. 2009. Knowledge-sharing and social interaction within MNEs. Journal of International Business Studies, 40(5): 719-741.

Oddou, G., Osland, J. S., \& Blakeney, R. N. 2009. Repatriating knowledge: Variables influencing the "transfer" process. Journal of International Business Studies, 40(2): 181-199.

Peltokorpi, V., \& Vaara, E. 2014. Knowledge transfer in multinational corporations: Productive and counterproductive effects of language-sensitive recruitment. Journal of International Business Studies, 45(5): 600-622.

Peterson, M. F., Arregle, J. L., \& Martin, X. 2012. Multilevel models in international business research. Journal of International Business Studies, 43(5): 451-457.

Powell, W. W. 1990. Neither market nor hierarchy: Network forms of organization. Research in Organizational Behavior, 12: 295-336.

Powell, W. W., Koput, K. W., \& Smith-Doerr, L. 1996. Interorganizational collaboration and the locus of innovation: Networks of learning in biotechnology. Administrative Science Quarterly, 41(1): 116-145.

Rosenkopf, L., \& Almeida, P. 2003. Overcoming local search through alliances and mobility. Management Science, 49(6): 751-766.

Sassen, S. 2005. The global city: Introducing a concept. Brown Journal of World Affairs, 11(2): 27-43.

Scalera, V., Perri, A., \& Hannigan, T. J. 2018. Knowledge connectedness within and across home country borders: Spatial heterogeneity and the technological scope of firm innovations. Journal of International Business Studies, 49: 990-1009.
Scott-Kennel, J., \& Giroud, A. 2015. MNEs and FSAs: Network knowledge, strategic orientation and performance. Journal of World Business, 50(1): 94-107.

Selmier, W. T., II, Newenham-Kahindi, A., \& Oh, C. H. 2015. "Understanding the words of relationships": Language as an essential tool to manage CSR in communities of place. Journal of International Business Studies, 46(2): 153-179.

Sharma, A., Kumar, V., Yan, J., Borah, S. B., \& Adhikary, A. 2019. Understanding the structural characteristics of a firm's whole buyer-supplier network and its impact on international business performance. Journal of International Business Studies, 50(3): 365-392.

Shaver, J. M. 2018. Headquarters economy: Managers, mobility, and migration. Oxford: Oxford University Press.

Shi, W. S., Sun, S. L., Pinkham, B. C., \& Peng, M. W. 2014. Domestic alliance network to attract foreign partners: Evidence from international joint ventures in China. Journal of International Business Studies, 45(3): 338-362.

Shijaku, E., Larraza-Kintana, M., \& Urtasun-Alonso, A. 2020. Network centrality and organizational aspirations: A behavioral interaction in the context of international strategic alliances. Journal of International Business Studies. https://doi. org/10.1057/s41267-018-0166-4.

Sigfusson, T., \& Chetty, S. 2013. Building international entrepreneurial virtual networks in cyberspace. Journal of World Business, 48(2): 260-270.

Spencer, J. W. 2003. Global gatekeeping, representation, and network structure: A longitudinal analysis of regional and global knowledge-diffusion networks. Journal of International Business Studies, 34(5): 428-442.

Stallkamp, M., Pinkham, B. C., Schotter, A. P. J., \& Buchel, O. 2018. Core or periphery? The effects of country-of-origin agglomerations on the within-country expansion of MNEs. Journal of International Business Studies, 49: 942-966.

Storper, M. 2018. Separate worlds? Explaining the current wave of regional economic polarization. Journal of Economic Geography, 18(2): 247-270.

Styles, C., Patterson, P. G., \& Ahmed, F. 2008. A relational model of export performance. Journal of International Business Studies, 39(5): 880-900.

Su, C., Yang, Z., Zhuang, G., Zhou, N., \& Dou, W. 2009. Interpersonal influence as an alternative channel communication behavior in emerging markets: The case of China. Journal of International Business Studies, 40(4): 668-689.

Taylor, P. J., \& Derudder, B. 2016. World city network: A global urban analysis (2nd ed.). London: Routledge.

Taylor, S. 2007. Creating social capital in MNCs: The international human resource management challenge. Human Resource Management Journal, 17(4): 336-354.

Tortoriello, M. 2015. The social underpinnings of absorptive capacity: The moderating effects of structural holes on innovation generation based on external knowledge. Strategic Management Journal, 36(4): 586-597.

Tortoriello, M., \& Krackhardt, D. 2010. Activating cross-boundary knowledge: The role of Simmelian ties in the generation of innovations. Academy of Management Journal, 53(1): 167-181.

Tortoriello, M., Reagans, R., \& McEvily, B. 2012. Bridging the knowledge gap: The influence of strong ties, network cohesion, and network range on the transfer of knowledge between organizational units. Organization Science, 23(4): 1024-1039.

Tröster, C., \& Van Knippenberg, D. 2012. Leader openness, nationality dissimilarity, and voice in multinational management teams. Journal of International Business Studies, 43(6): 591-613.

Tsai, W. 2001. Knowledge transfer in intraorganizational networks: Effects of network position and absorptive capacity on business unit innovation and performance. Academy of Management Journal, 44(5): 996-1004. 
Turkina, E., \& Van Assche, A. 2018. Global connectedness and local innovation in industrial clusters. Journal of International Business Studies, 49: 706-728.

Useche, D., Miguelez, E., \& Lissoni, F. 2020. Highly skilled and well connected: Migrant inventors in cross-border M\&As. Journal of International Business Studies. https://doi.org/10. 1057/s41267-018-0203-3.

Uzzi, B. 1997. Social structure and competition in interfirm networks: The paradox of embeddedness. Administrative Science Quarterly, 42(1): 35-67.

Vasudeva, G., Zaheer, A., \& Hernandez, E. 2013. The embeddedness of networks: Institutions, structural holes, and innovativeness in the fuel cell industry. Organization Science, 24(3): 645-663.

Venaik, S., Midgley, D. F., \& Devinney, T. M. 2005. Dual paths to performance: The impact of global pressures on MNC subsidiary conduct and performance. Journal of International Business Studies, 36(6): 655-675.

Walter, J., Lechner, C., \& Kellermanns, F. W. 2007. Knowledge transfer between and within alliance partners: Private versus collective benefits of social capital. Journal of Business Research, 60(7): 698-710.

Wang, D. 2015. Activating cross-border brokerage: Interorganizational knowledge transfer through skilled return migration. Administrative Science Quarterly, 60(1): 133-176.

Wellman, B. 1988. Network as personal communities. In B. Wellman \& S. D. Berkowit (Eds), Social structures: A network approach. Cambridge: Cambridge University Press.

Westney, D. E., \& Sakakibara, K. 1985. The role of Japan-based R\&D in global technology strategy. Technology in Society, 7(2-3): 315-330.

Xia, J., Ma, X., Tong, T. W., \& Li, W. 2018. Network information and cross-border M\&A activities. Global Strategy Journal, 8(2): 301-323.

Xiao, Z., \& Tsui, A. S. 2007. When brokers may not work: The cultural contingency of social capital in Chinese high-tech firms. Administrative Science Quarterly, 52(1): 1-31.

Zaheer, A., \& Zaheer, S. 1997. Catching the wave: alertness, responsiveness, and market influence in global electronic networks. Management Science, 43(11): 1493-1509.

Zaheer, S., Lamin, A., \& Subramani, M. 2009. Cluster capabilities or ethnic ties? Location choice by foreign and domestic entrants in the services offshoring industry in India. Journal of International Business Studies, 40(6): 944-968.

Zhang, J., \& Pezeshkan, A. 2016. Host country network, industry experience, and international alliance formation: Evidence from the venture capital industry. Journal of World Business, 51: 264-277.

Zhou, K. Z., Poppo, L., \& Yang, Z. 2008. Relational ties or customized contracts? An examination of alternative governance choices in China. Journal of International Business Studies, 39(3): 526-534.

\section{ABOUT THE AUTHORS}

Ilya $\mathbf{R} \mathbf{P}$ Cuypers is an Associate Professor of Strategy at the Lee Kong Chian School of Business,
Singapore Management University. He received his Ph.D. in strategy and international business from Tilburg University. His current research focuses on the governance, dynamics, and performance implications of cross-border external corporate development activities, investment decisions under uncertainty, and issues related to interorganizational ties.

Gokhan Ertug is Professor of strategic management at the Lee Kong Chian School of Business, Singapore Management University. He received his Ph.D. from INSEAD. His research interests include social networks, status, reputation, and international business.

John Cantwell is Distinguished Professor of International Business at Rutgers University, Newark, NJ, USA. His research focuses on technological innovation and international knowledge networks. His published research spans the fields of International Business, Economics, Economic History, Philosophy, Economic Geography, and Innovation Studies. He has been Program Chair of the AIB, President of EIBA, and he is an elected AIB Fellow.

Akbar Zaheer (Ph.D. MIT) is Professor and Curtis L. Carlson Chair in Strategic Management at the Carlson School of Management, University of Minnesota. Besides a deep interest in organizational networks and global strategy, he also studies innovation, trust in global and organizational settings, and strategic alliances.

Martin Kilduff (Ph.D. Cornell, 1988) is Professor of Organizational Behavior at the UCL School of Management and former editor of Academy of Management Review (2006-2008). He previously held positions at INSEAD, Penn State, University of Texas at Austin, and Cambridge University. His research focuses on the micro-foundations and consequences of individuals' social networks.

Publisher's Note Springer Nature remains neutral with regard to jurisdictional claims in published maps and institutional affiliations.

Accepted by Yadong Luo, Senior Editor, 20 February 2020. This article has been with the authors for one revision and was single-blind reviewed. 